\title{
Evidence for Archean Ocean Crust with Island Arc Signature from Diamondiferous Eclogite Xenoliths
}

\author{
Jacob, D.E. and Foley, S.F.
}

Mineralogisch-Petrologisches Institut, University of Göttingen, Goldschmidtsr.1, D-37077 Göttingen, Germany

A suite of previously well described diamondiferous eclogites from the Udachnaya kimberlite in Siberia (Jacob et al., 1994) was measured for a range of trace elements by Laser Ablation ICP-MS (LAM) at the Memorial University of Newfoundland. The rocks are essentially bimineralic and consist of garnet and cpx in various amounts, although each sample contains several diamonds. Except for one sample, no Ti-rich oxide phase such as rutile or illmenite is present. Earlier work on these samples comprised major element concentrations, oxygen isotopes, radiogenic isotopes ( $\mathrm{Rb}-\mathrm{Sr}$, $\mathrm{Sm}-\mathrm{Nd}, \mathrm{Pb}-\mathrm{Pb}$ ) for cpx and garnet as well as carbon isotopes. Jacob et al. (1994) could show that this sample suite represents subducted altered oceanic seafloor of late Archean age (2.76 Ga) comparable to the suite of eclogites from Roberts Victor, South Africa.

This study here was undertaken in order to further constrain the primary composition of Archean oceanic crust and to unravel the seawater alteration history of the eclogites.
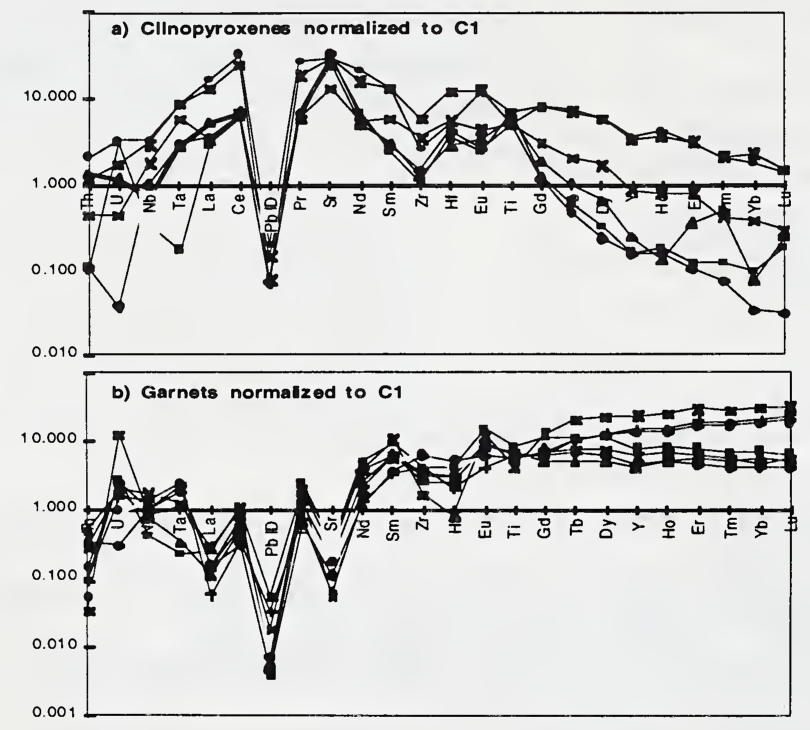

\section{Results}

Figure 1 shows the chondrite-normalized spidergrams for both garnet and clinopyroxene in the studied eclogites. Concentrations of all trace elements are in the range of those observed in eclogite xenoliths in general; Pb contents, however, are lower than in Roberts Victor eclogites (Jacob, 1995).

Oxygen isotopic ratios range between 5.19 and $7.26 \%$ which is distinctly different from the average mantle composition of $5.5 \%$ (Mattey et al., 1994), but narrower than the $\delta^{18} \mathrm{O}$ range for Roberts Victor eclogites (2.2-8.4; MacGregor and Manton, 1986). On the basis of $\delta^{18} \mathrm{O}$ and loosely following the classification of Jagoutz et al. (1984), two groups of samples can be differentiated:

Group I (or A), representing upper oceanic crust has $\delta^{18} \mathrm{O}>5.5 \%$, low $\mathrm{CaO}$, low $\mathrm{La} / \mathrm{Lu}$ in garnet, high HREE, higher $\mathrm{Y}$ and higher $\mathrm{Zr} / \mathrm{Hf}$ in garnet and no positive Eu-anomaly.

Group II (or B), representing the lower part of the oceanic crust has $\delta^{18} \mathrm{O}<5.5 \%$, higher $\mathrm{CaO}$, high $\mathrm{La} / \mathrm{Lu}$ in garnet, a flat HREE pattern, lower $\mathrm{Y}$ and $\mathrm{Zr} / \mathrm{Hf}$ in garnet and positive Eu-anomalies.

Interestingly, positive Eu-anomalies occur in group A eclogites at Roberts Victor, whereas they seem to be restricted to group B (or II) eclogites at Udachnaya. 
Effects of seawater alteration on the eclogite precursors can be shown by plots of elements or elemental ratios versus $\delta^{18} \mathrm{O}$ which show a typical two-winged shape (Fig. 2). These correlations with $\delta^{18} \mathrm{O}$ are consistent for all trace elements in group I and II samples that were mobile during seawater alteration of the eclogite precursors.

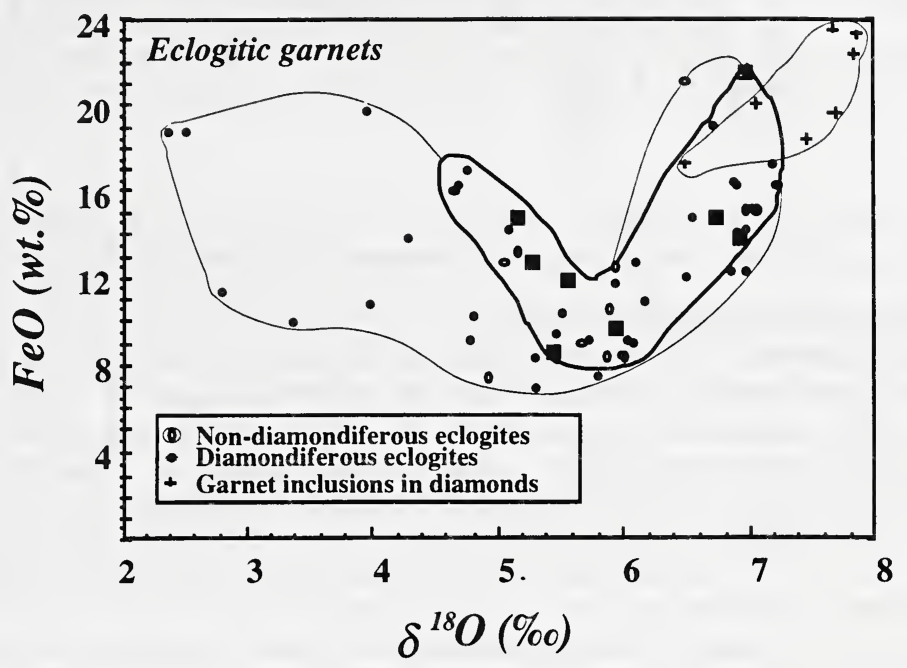

Fig.2 Correlation between $\delta^{18} \mathrm{O}$ and $\mathrm{FeO}$ in eclogitic garnets from kimberlites in Siberia (Udachnaya; Jacob et al., 1994) and South Africa (Finsch, Jagersfontein, Kaalvallei, Roberts Victor; unpublished data from the Royal Holloway Laboratory).

\section{Discussion}

In order to compare our data with bulk rock data for basaltic rocks, we have calculated "clean" bulk compositions, using mineral data and assuming equal modal amounts of garnet and cpx. This is valid because (1) all samples except one (which is excluded from further discussion) are bimineralic, and (2) it can be shown that the trace element patterns do not change considerably as a function of shifts in modal amount of garnet and cpx. The advantage of this method is that metasomatic effects (e.g. by the kimberlitic magma) are excluded.

The restored whole-rocks are basalt (group II; $9-12 \% \mathrm{MgO}$ ) to picrite (group I; $12-18 \% \mathrm{MgO}$ ) in composition. The other most noticeable feature is extremely low $\mathrm{TiO}_{2}$ contents. Amongst modern volcanic rocks, such low $\mathrm{TiO}_{2}$ contents are typical of arc-related rocks, although they are common in Archean komatiites. Komatiites have similarly low $\mathrm{TiO}_{2}$, but also much lower $\mathrm{Al}_{2} \mathrm{O}_{3}$, whereas most Archean basalts are only similar if the eclogites represent residues after melting. The eclogites plot in the field of modern arc low-K tholeiites, and are distinctly different from MORB (or OIB). The $\mathrm{Al}_{2} \mathrm{O}_{3} / \mathrm{TiO}_{2}$ of the eclogites is higher than any known Archean volcanic.

Rudnick (1995) showed that eclogite xenolith $\mathrm{SiO}_{2}$ contents are markedly lower than those of Archean volcanics, and attributed this to loss of a silica-rich melt. The Udachnaya eclogites, however, have relatively high $\mathrm{SiO}_{2}$, so it cannot be ascertained whether or not they are residues after melt loss. There are too few samples from each group to confidently construe any primary igneous fractionation trends as an alternative to melt loss during subduction.

Mantle-normalised incompatible element patterns clearly show the grouping in terms of HREE contents, positive Sr-anomaly, and strong depletion in Th and $\mathrm{U}$. The latter elements are strongly remobilised during hydrothermal alteration and subduction. Since the eclogites most resemble modern arc low-K tholeiites in terms of major elements, the arc-normalised trace element patterns are presented in Fig.3. Allowing for the effects of hydrothermal alteration on the ocean floor and subsequent subduction metamorphism, these patterns are very similar, agreeing with the major element characterisation of the samples as arc basalts. 


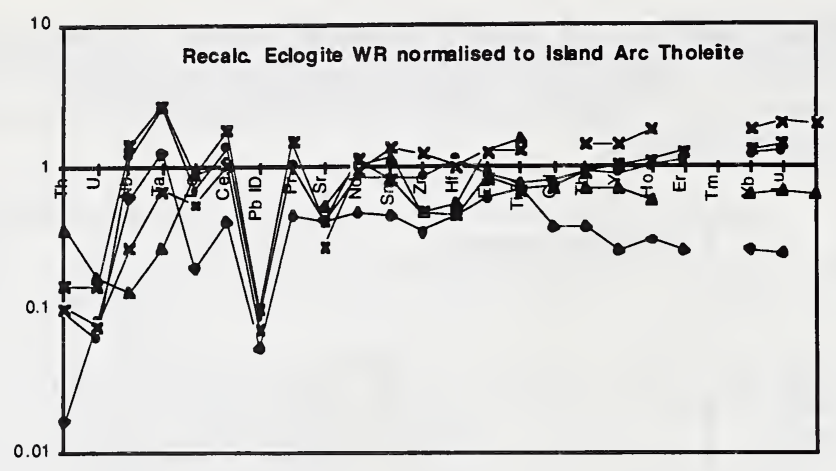

\section{Implications for Archean crustal processes}

We cannot be sure if the "arc" eclogites are typical of Archean oceanic crust, or whether rocks of this composition are preferentially preserved due to their proximity to continental margins. The incorporation of the subducted oceanic crust into the cratonic lithosphere probably indicates subduction beneath a continental margin. Many modern back-arc basin basalts are difficult to distinguish from arc basalts, so that subduction of the crust of a relatively small marginal basin cannot be discounted. If the eclogites are typical of oceanic crust at the end of the Archean, this would be consistent with models for more numerous, small oceanic plates with basalts which are rarely free of the influence of nearby island arcs.

$\mathrm{Nb} / \mathrm{Ta}$ for the eclogites is about 7, which is notably lower than for primitive mantle, MORBs and even island arc basalts and accepted values for the continental crust (11-12). Thus, if these eclogites are typical of Archean ocean crust, then this subducted crust cannot form the residual counterpart to the continental crust.

\section{References}

Jacob, D., 1995, Isotopenpetrologie von diamantführenden eklogitischen Xenolithen aus Udachnaya, Sibirien - auf der Spur der archaischen Ozeankruste, Ph.D. Thesis, Universität Göttingen, FRG.

Jacob, D., Jagoutz, E., Lowry, D., Mattey, D. and Kudrjavtseva, G., 1994, Diamondiferous eclogites from Siberia: Remnants of Archean oceanic crust: Geochim. Cosmochim. Acta 58, 51915207 .

Jacob, D. and Jagoutz, E., 1995, A diamond-graphite bearing eclogitic xenolith from Roberts Victor (South Africa): Indications for petrogenesis from $\mathrm{Pb}-, \mathrm{Nd}-$ and $\mathrm{Sr}-$ isotopes. In Kimberlites, Related Rocks and Mantle Xenoliths (H. O. A. Meyer and O. H. Leonardos, eds.), CPRM Spec. Publ. 1/95. Jagoutz, E., Dawson, J. B., Hoernes, S., Spettel, B. and Wänke, H., 1984, Anorthositic oceanic crust in the Archean Earth: 15th Lunar Planet. Sci. Conf. , 395-396. (abs).

MacGregor, I. D. and Manton, W. I., 1986, Roberts Victor eclogites: ancient oceanic crust: J. Geophys. Res. 91(B14), 14063-14079.

Mattey, D., Lowry, D. and MacPherson, C., 1994, Oxygen isotope composition of mantle peridotite: Earth Planet. Sci. Lett. 128, 231-241.

Rudnick, R.L., 1995, Eclogite xenoliths: samples of Archean ocean floor, Ext. Abstr. 6th Intern. Kimberlite Conf., 473-475. 